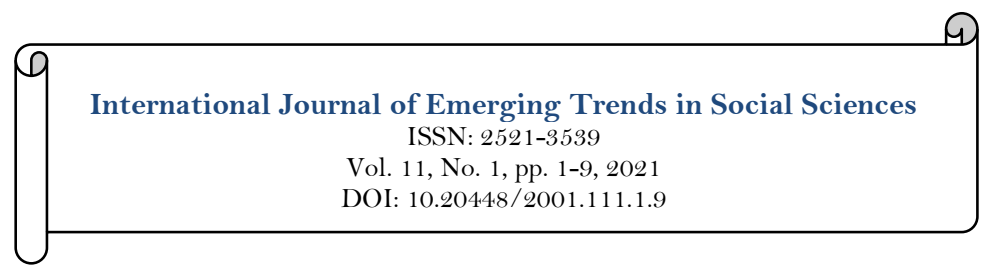

check for
updates

\title{
Earnings Quality: Impact of Income Smoothing, Earnings Persistence, Book Tax Difference with Good Corporate Governance as Moderation
}

\section{Feber Sormin ${ }^{14}$ \\ Titik Aryati ${ }^{2}$}

${ }^{1,2}$ Faculty of Economics and Business, Trisakti University, Indonesia.

Email:febersormin.umb@gmail.com

\begin{abstract}
This study has a purpose to determine the effect of Income Smoothing, Earnings Persistence, Book Tax Difference on Earnings Quality and moderating effect of Good Corporate Governance. Using 98 sample data from manufacturing entities on the Indonesia Stock Exchange in 20152020, a negative effect of earnings persistence on earnings quality, and a positive effect of differential book tax on earnings quality found in this study, while income smoothing does not. In addition, it was found that good corporate governance by institutional ownership as a proxy strengthens the effect of income smoothing on earnings quality and weakens the effect of book-tax differences on earnings quality. This finding can be used by investors in assessing the quality of earnings from financial information issued by issuers so that future earnings prediction analysis can be measured properly so that the desired return target is achieved.
\end{abstract}

Keywords:

Earnings quality

Income smoothing

Earnings persistence

Book tax difference

Good corporate governance.

JEL Classification

L1 5; H25; G3O

Licensed:

This work is licensed under a

Creative Commons Attribution 4.0

License.

Publisher:

Scientific Publishing Institute

Received: 21 May 2021

Revised: 29 June 2021

Accepted: 2 August 2021

Published: 26 August 2021

( Corresponding Author)

Funding: This study received no specific financial support.

Competing Interests: The authors declare that they have no competing interests.

\section{Introduction}

Management in managing financial statements often takes a series of actions by exploiting weaknesses in the accounting recording method or system, so that the financial statements presented are no longer following the company's real economic conditions. Whereas financial statements should meet certain qualitative characteristics to provide useful information for users. The four main qualitative characteristics of financial accounting standards are understandable, relevant, reliable, and comparable (Kartikahadi, Sinaga, Syamsul, Siregar, \& Wahyuni, 2016). The decrease in transparency result in the increasing implementation of earnings management in company (Aryati \& Walansendouw, 2013). It is evident from the many cases of income smoothing found from financial statement investigations, as well as inflation of financial posts to manage earnings quality in the corporate financial statement.

Scott (2012) explained that earnings quality is a criterion considered in measuring how quality information in the financial statements can describe the actual condition of the company. PSAK 1 Paragraph 
28 states that when accrual-based accounting is used, the entity recognizes items as assets, liabilities, income, and expenses as well as the recognition criteria in the basic framework of financial statements. Sumbari, Murni, and Masri (2017) in their research detects the existence of earnings management carried out using various accrual measures such as abnormal accruals and total accruals. Richardson, Sloan, Soliman, and Tuna (2001) stated information of current and non-current accruals analysed for get the information of earnings quality.

In their research, Ezat et al. (2019) mentions Earnings Quality represents the ability of income to be expressed in revealing the actual performance of the economic unit in addition to the continuity of income for future periods, as well as its current ability to predict future income. Novianti (2012) states that the earnings quality in particular and the financial reports quality, in well-known, are important for those who use financial statements because it's miles for contractual purposes and investing.

Harry (2015) said that managers who do profit distribution want to get various economic and psychological benefits. Income smoothing as implies for supervisors to reveal their individual data approximately future profit (Demski, 1998; Kirschenheiter \& Melumad, 2002; Ronen \& Sadan, 1981; Sankar \& Subramanyam, 2001). Kirschenheiter and Melumad (2002) appear that detailed profit have a double part. Hunt, Moyer, and Shevlin (2000) found that Income Smoothing upgrades the modern price-earnings relationship, recommending that pay smoothing increments profit usefulness. Income smoothing can be achieved in two ways (Harry, 2015), namely by Real Smoothing or income smoothing carried out through actual financial transactions by influencing profits through intentional changes to operating policies, the second is Artificial smoothing, namely income smoothing through applied accounting procedures to transfer costs and/or revenues from one period to another. The results of Shubita (2015) found that there income smoothing has a positive effect on earnings quality. However, in contrast to the results of research by Kangarlouei, Motavassel, and Rezvani (2012) who did not find the influence of income smoothing on earnings quality.

Another factor regarding earnings quality is earnings persistence. Scott (2009) expressed that earnings persistence could be the amendment of anticipated profit within the future that can be implied by the current year's earnings associated with changes in stock prices. Revision of profits can occur due to the application of taxation that makes accounting profits change, where each has a different utilization purpose. According to Djamaludin, Wijayanti, and Rahmawati (2008), the difference between accounting profit and fiscal profit can provide information about management discretionary accruals. The results of Kevin (2011) explain that the restatement of financial statements appears a more noteworthy increment in profit determination from the two a long time some time recently to the two a long time after the repetition. The consider of Ames, Hines, and Sankara (2014) finds that way better profit perseverance, higher quality of collections, and less smoothing of profit are reflected in higher FSR, with a bigger impact size for private protections companies. Dridi and Adel (2016) found that tirelessness was lower than the bunch with positive DBTD and little DBTD, reflecting altogether lower determination than the other bunches. Himmah (2018) in his investigate found the impact of the gathering component of profit perseverance on earnings quality.

Within the application of bookkeeping records, there may be contrasts between the planning of monetary bookkeeping measures and charge controls, and of course, this will result totally different bookkeeping benefits from charge benefits or books-tax contrasts (BTD). Contrasts that regularly emerge from the treatment of the planning of these money related articulations are lasting and transitory. Hery (2010) clarifies that the contrast in benefit between charges and Monetary Bookkeeping Measures is the result of a handle of assess alterations and redresses from commercial reports to charge reports carried out by administration. The distinction between bookkeeping benefit and financial benefit or book-tax contrast can give data approximately profit quality (Tang, 2006). Huang and Wang (2013) clarified that a expansive books assess distinction shows a potential "hail ruddy" from low earnings quality. Besides, Huang and Wang (2013) too found that banks with expansive brief book-tax contrasts have profit determination and littler collections one year ahead than those with little transitory book-tax contrasts. Sari and Lyana (2016) found the impact of book-tax contrasts on earnings quality.

Directions in Indonesia through PER-01/MBU/2011 clarify that Great Corporate Administration is the guideline that underlies prepare and component for overseeing a company based on laws and directions and commerce morals. The concept of corporate administration was made with the point that the administration of the company is made more Straightforwardness, Responsibility, Responsibility, Autonomy, Decency, for all parties who utilize monetary explanations. Hery (2010) clarifies that Great Corporate Administration may be a set of directions that control the relationship between shareholders, company administration, leasers, government, workers, and other inside and outside partners related to their rights and commitments. Since the 1998 financial emergency, numerous companies have collapsed since they are considered not to have great corporate administration. The concept of corporate administration was made with the point that the administration of the company is made more.

The Good Corporate Governance component can be partitioned into two parts, to be specific the Inside Administration instrument, counting the extent of Free Commissioners, administrative possession, regulation possession, review quality, official recompense, and Outside Administration instruments such as showcase control and obligation financing levels (Barnhat \& Rosenstein, 1998). Murwaningsari (2014) in his 
inquire about concludes that the more prominent the regulation possession, the higher the level of supervision that can be carried out by regulation possession so that it can energize administration to reveal data more comprehensively. Tehranian, Cornett, Marcus, and Saunders (2006) expressed that supervisory activities were taken by a company and organization financial specialists can restrain the directors' behaviour. Guthrie and Petty (2000) discover prove that firms tend to control their profit around equity offerings experienced within the nearness of huge exterior square possessions. Based on the description above, the researcher uses Institutional Ownership as a proxy of GCG as a moderating variable.

Investigate Mehrani, Moradi, and Eskandar (2017) found a positive impact of organization proprietorship on profit quality. Moreover, Alhadi, Senik, and Johari (2018) concludes that organization proprietorship is viable in moving forward Gaining Quality. Inquire about comes about (Zhong, Chourou, \& $\mathrm{Ni}, 2017$ ) report that there's a positive relationship between regulation proprietorship technique and the quality of corporate profit. These comes about are diverse from Himmah (2018) which did not discover the impact of GCG on earnings quality.

\section{Literature Review}

The Signalling theory created by Ross (1977) states that company officials who have superior data around their company will be energized to communicate this data to potential speculators so that the company's stock cost increments. The positive thing in signalling hypothesis is that companies that give great data will separate them from companies that don't have "great news" by educating the showcase almost their circumstance. Application of Signal Theory (Signalling theory) on earnings quality, can be seen from the presentation of the financial statements presented in the financial statements. The earnings quality disclosed in the corporate's financial statements will certainly be able to trigger a reaction of investor interest to immediately own company shares in the market. In terms of giving this positive signal, it is not uncommon for managers to carry out income-generating practices through income smoothing, earnings persistence, earnings persistence, as well as through differential tax books through recording adjustments in the bookkeeping process between Accounting Standards and Tax Reporting Standards that are beneficial for the company to improve the quality of corporate earnings and even ignore the Good Corporate Governance mechanism that has been regulated in the regulations.

On the other hand, the Agency Theory developed by Jensen and Meckling (1976) defined the relationship between agents and principals. The relationship between agency theory and earnings quality is of course very closely related, where each party involved will take a series of actions that benefit his party such as management. Company management as an agent who best knows the condition of the company will certainly try to provide good company performance to the owner through quality profit report information in an accounting period, so that owners or investors can continue to trust management to continue the company's business The urge to want good company performance results is one of the triggers for management to carry out any practice to maintain its performance in the company, such as managing income smoothing, carrying out profit persistence, and also using Books Tax Differences in earnings management by utilizing its components and adjust the conditions on Good Corporate Governance owned by the company.

\subsection{Income Smoothing on Earnings Quality}

Tucker and Zarowin (2006) expressed that income smoothing is characterized as 'efforts on the portion of company administration to diminish anomalous varieties in profit to the degree allowed beneath sound bookkeeping and administration principles' (Beidleman, 1973). Income smoothing can be achieved in two ways (Harry, 2015), namely Real Smoothing which is carried out through actual financial transactions by influencing profits through intentional changes to operating policies, and Artificial smoothing, namely, income smoothing through accounting procedures applied to transfer costs and/ or income from one period to another. To find out whether a company is included in the group that performs income smoothing or not, Eckel (1981) used the index. Hunt et al. (2000) found that income smoothing increments profit information. Shubita (2015) has found positive impact of income smoothing on earnings quality, with noteworthy prove based on the profit alter demonstrate.

H1. Income smoothing has a positive effect on earnings quality.

\subsection{Earnings Persistence on Earnings Quality}

The persistence of accounting earnings is a revision in the expected future accounting profit that is implied by the current year's accounting profit (Asma, 2013; Djamaludin et al., 2008). Revision of profits can occur due to the application of taxation that makes accounting profits change, where each has a different utilization purpose. As we know in the application of Accounting Standards, companies can use the measurement of tax profit. So it is unavoidable the difference between tax profit and accounting profit. According to Djamaludin et al. (2008), the difference between accounting profit and fiscal profit can provide information about management discretionary accruals. The comes about of Kevin (2011) clarify that rehashing companies appear a more prominent increment in earnings persistence from the two a long time 
some time recently to the two a long time after the rehashing. Besides, Ames et al. (2014) clarify that superior earnings persistence, higher accrual quality, and less smoothing of profit are reflected in higher FSR for open and private protections companies, with a bigger impact greatness for private protections companies. The comes about of Himmah (2018) state that the collection component of profit tirelessness includes a noteworthy and critical impact on earnings quality.

H2. Earnings persistence has a positive effect on earnings quality.

\subsection{Book Tax Difference on Earnings Quality}

The application of different accounting records between SAK and tax regulations will certainly result in different company profits or books-tax differences. Books-tax differences or differences in profit between taxes and Financial Accounting Standards are the results of a process of tax adjustments and corrections from commercial reports to tax reports carried out by management. This adjustment and correction process will certainly lead to earnings management opportunities as a result of the impact of the company's economic conditions and company management policies. The ability of managers to treat the application of rules in the fiscal correction process will certainly result in the manipulation of accounting profit reporting. The difference between accounting profit and fiscal profit can provide information about earnings quality (Tang, 2006). Lev and Nissim (2004) give prove that book-tax contrasts can foresee future profit development. Hanlon (2005) found that book-tax contrasts are exceptionally solid in appearing profit perseverance and estimating wage, gatherings, and cash streams for one year's salary. Sari and Lyana (2016) found the impact of book-tax contrasts on profit quality.

H3. Book Tax Difference has a positive effect on earnings quality.

\subsection{Good Corporate Governance on Impact Income Smoothing, Earnings Persistence and Book Tax Difference on Earnings} Quality

According to Hery (2010) Good Corporate Governance may be a set of directions that control the relationship between shareholders, company administration, banks, government, workers, and other inside and outside partners related to their rights and commitments. Pasaribu, Topowijono, and Sulasmiyati (2016) declared that institutional ownership is the rate of offers possessed by teach. Yuniati, Raharjo, and Oemar (2016) proceeded that institutional ownership is the level of share proprietorship by teach within the company, measured by the extent of offers claimed by educate at the conclusion of the year communicated as a percentage. Institutional speculators are powerful decision-makers and they have tall possession within the company and this acts as an effective observing component (Zhong et al., 2017). Murwaningsari (2014) clarifies that the more noteworthy the institutional ownership, the higher the level of supervision that can be carried out by institutional ownership so that it can energize administration to reveal data more comprehensively. Mehrani et al. (2017); Alhadi et al. (2018); Zhong et al. (2017) found a positive impact of institutional ownership on earnings quality.

H4a. Good corporate governance strengthens the effect of Income Smoothing on Earnings Quality.

H4b. Good corporate governance strengthens the effect of earnings persistence on Earning Quality

H4c. Good corporate governance strengthens the effect of the book-tax difference on Earning

Quality.

\section{Method}

\subsection{Design}

This investigate is quantitative inquire about with auxiliary information. The information utilized are 32 samples of manufacturing companies within the food and Beverage sub-sector recorded on the Indonesia Stock Exchange from 2015 to 2020. The type of research is causal research by analysing 98 data by purposive sampling as described in Table 1.

Table-1. Purposive Sampling

\begin{tabular}{c|l|c}
\hline No. & Criteria & Amount \\
\hline 1 & Food and Beverage Subsector Manufacturing Company, Listed on the IDX in 2020 & 32 \\
\hline 2 & $\begin{array}{l}\text { Manufacturing Company in the F\&B Subsector, which recently IPO on the IDX in } \\
2015-2020\end{array}$ & -3 \\
\hline 3 & $\begin{array}{l}\text { F\&B Subsector Manufacturing Companies on IDX that suffered losses or had } \\
\text { incomplete data in 2015-2020 }\end{array}$ & -11 \\
\hline & Total Sample & 18 \\
\hline & Multiplied by 6 years of observation (2015-2020) & 108 \\
\hline & Outlier Data & -10 \\
\hline & Amount of data analysed & 98 \\
\hline
\end{tabular}


3.2. Variables

3.2.1. Dependent Variables

The earnings quality (EQ) is dependent variable of this study, which is earnings that reflect the company's actual financial performance (Irawati, 2012). It was measured using the Revenue Discretionary Model developed by Stubben (2010) and used in the research of Gultom and Ahmar (2016).

\subsubsection{Independent Variables}

There are three independent variables analysed in this study, namely income smoothing, earnings persistence, and book-tax differences. Tucker and Zarowin (2016) define income smoothing as an exertion on the portion of company administration to diminish anomalous varieties in profit to the degree allowed beneath sound bookkeeping and administration principles' (Beidleman, 1973). The index from Eckel (1981) is used in this study to determine whether a company is included in the group that performs income smoothing or not, as also used in the research of Pratiwi and Handayani (2014). Scott (2009) defines earnings persistence as the modification of anticipated future profit suggested by current year profit related with changes in stock costs. Hanlon (2005) and Blaylock, Shevlin, and Wilson (2012) utilize a condition where persistence is evaluated through income before tax for another year. Dridi and Adel (2016) created a show in which taxable income is assessed on their component which is pre-tax income and all recuperations and deductions for all alterations. Books Tax Differences are within the shape of earnings differences based on book value and tax value, alluding to the inquiry of Tang and Firth (2012), Fontanella and Martani (2014), Rusydi and Martani (2014), and Sismi and Martani (2014), BTD is calculated by dividing the difference between accounting earnings and tax earnings with the fixed assets.

\subsubsection{Moderating Variables}

Hery (2010) defines Good Corporate Governance as a set of controls that control the relationship between shareholders, company administration, lenders, government, workers, and other inner and outside partners related to their rights and commitments. Yuniati et al. (2016) clarified that institutional ownership is the level of share possession by teach within the company, measured by the extent of offers claimed by educate at the conclusion of the year communicated as a rate. The level of the institutional ownership is measured by the rate of share of institution by share of corporate (Yuniati et al., 2016).

\subsubsection{Control Variables}

We utilize five control factors to fortify the inquire about demonstrate, specifically firm size as measured by the log of the reduction in total assets with loss reserve assets and deferred tax assets, solvency ratio as measured by DAR, namely the ratio of total liabilities to total assets.

3.3. Research Model

The regression estimates for hypothesis test as follow:

$\mathrm{EQ}=\beta_{0}+\beta_{1} \mathrm{IS}+\beta_{2} \mathrm{EP}+\beta_{3} \mathrm{BTD}+\beta_{4} \mathrm{Size}+\beta_{5} \mathrm{DAR}+\varepsilon$

$\mathrm{EQ}=\beta_{0}+\beta_{1} \mathrm{IS} * \mathrm{GCG}+\beta_{2} \mathrm{EP} * \mathrm{GCG}+\beta_{3} \mathrm{BTD}^{*} \mathrm{GCG}+\beta_{4}$ Size $+\beta_{5} \mathrm{DAR}+\varepsilon$

Using SPSS software, we analysed research data by starting with classical assumption tests such as normality test, multicollinearity test, heteroscedasticity test, and autocorrelation test, then Fit test and coefficient of determination test using adjusted r-square, until t-test to analyse the hypothesis.

4. Result

4.1. Descriptive Statistics

Table-2. Descriptive Statistics

\begin{tabular}{c|c|c|c|c}
\hline Variable & Mean & Std. Dev & Min & Ma \\
\hline EQ & 30.4494 & 1.3951 & 26.5046 & 33.6735 \\
\hline IS & 1.6718 & 1.4498 & -0.9871 & 4.0442 \\
\hline EP & 3.2207 & 1.5077 & -1.8326 & 4.3857 \\
\hline BTD & 0.0399 & 0.0381 & -0.0037 & 0.1827 \\
\hline GCG & 0.7744 & 0.1448 & 0.5009 & 0.9956 \\
\hline SIZE & 28.7617 & 1.3539 & 26.7230 & 31.8662 \\
\hline DAR & O.4467 & O.1797 & O.1152 & 0.8905 \\
\hline Note: EQ = Earnings Quality, IS = Income Smoothing, EP = Earnings Persistence,
\end{tabular}

$\mathrm{BTD}=$ Book Tax Difference, $\mathrm{GCG}=$ Good Corporate Governance, SIZE =

Corporate Size, DAR = Debt to Asset Ratio

Table 2 shows the statistical value of each research variable. The average value of each variable is higher than the standard deviation value, this explains that the data analysed is good. 


\subsection{Regression Result}

Table 3 shows the results of the main regression test for each of the independent without moderating and control variables. It is known that income earnings persistence harms earnings quality and the book-tax difference has a positive effect on earnings quality, while income smoothing does not have a significant effect on earnings quality.

Table-3. Main Regression result

\begin{tabular}{c|c|c}
\hline Variables & Coefficient & Sig. \\
\hline IS & 0.051 & 0.578 \\
\hline EP & -0.277 & $0.004^{* * *}$ \\
\hline BTD & 12.104 & $0.001^{* * *}$ \\
\hline N & 98 & \\
\hline Adj. R & 0.252 & \\
\hline Prob. F-Stat & O.OOO & \\
Note: EQ = Earnings Quality, IS = Income Smoothing, EP = Earnings \\
Governance, STD = Book Tax Difference, GCG = Good Corporate \\
* for significant 10\%, ** for significant $5 \%$, *** for significant $1 \%$
\end{tabular}

Based on these results, hypothesis 1 is rejected, meaning that income smoothing does not influence earnings quality. These results explain that companies that carry out income smoothing do not mean that they only aim for earnings management, but there is a possibility that they have other goals, especially for companies that have long been established to maintain the good name of the company so that it also has no impact on earnings quality. The comes about of the think about are in line with Kangarlouei et al. (2012) who moreover did not discover a critical relationship between income smoothing and earnings quality.

Based on Table 3 also show that earnings persistence hurts earnings quality. Therefore, hypothesis 2 is rejected. The results of this study prove that the use of earnings persistence through the company's earnings management elements in regulating profit fluctuations, so suddenly there are times when high profits in disclosure of reports and has caused the quality of earnings to be informed to the public to decrease. Pressure on management to provide information that the company has good profits makes management give a signal to maintain confidence in the company's sustainability in the future. However, this condition gives a signal that the quality of earnings disclosed in the financial statements is increasing of doubtful quality. The company can carry out earnings management by utilizing accruals to show stable and quality earnings. These results prove the research of Kevin (2011), Ames et al. (2014) and Himmah (2018) who found the effect of earnings persistence on earnings quality.

Based on the Table 3 also show that book-tax difference has a positive effect on earnings quality. Therefore, hypothesis 3 is accepted. The results of this study indicate that BTD can be considered as an internal control for companies to follow the rules, both accounting standards, and tax regulations. Accounting and tax accounting standards directly guide management as controllers to follow reporting according to tax regulations, so that indirectly recorded costs meet regulatory standards, and this has a positive impact on the quality of earnings that are informed. The larger the fiscal correction, of course, it shows a signal that the number of costs incurred by the company is not related to the main purpose of the company's activities, especially the correction of expenses for the interests of the owners, commissioners, or directors of the company Implementing BTD properly is also a means of reducing tax risk which can reduce additional burdens that can reduce company profits from what should be avoided. The regulation on BTD has made management place BTD as one of the internal controls in every financing. This is in line with Tang (2006); Sari and Lyana (2016) who found the effect of BTS on earnings quality.

Table-4. Moderating result.

\begin{tabular}{c|c|c}
\hline Variables & Coefficient & Sig. \\
\hline IS & -4.698 & 0.00 O $^{*} *$ \\
\hline IS*GCG & 5.448 & 0.00 * $^{*} *$ \\
\hline EP & 0.207 & 0.767 \\
\hline EP*GCG & -0.317 & 0.705 \\
\hline BTD & 56.346 & $0.001^{* * *}$ \\
\hline BTD*GCG & -68.966 & $0.002^{* * *}$ \\
\hline SIZE & 0.674 & $0.000^{*} * *$ \\
\hline DAR & 1.722 & $0.004^{* * *}$ \\
\hline N & 98 & \\
\hline Adj. R & 0.667 & \\
\hline Prob. F-Stat & 0.000 & \\
\hline
\end{tabular}

Note: $\mathrm{EQ}=$ Earnings Quality, IS = Income Smoothing, EP = Earnings Persistence, BTD = Book Tax

Difference, $\mathrm{GCG}=$ Good Corporate Governance, $\mathrm{SIZE}=$ Corporate Size, DAR = Debt to Asset Ratio.

* for significant $10 \%$, ** for significant $5 \%$, *** for significant $1 \%$ 
Based on these results in the Table 4, hypothesis 4a is accepted, meaning that good corporate governance strength affects income smoothing on earnings quality. The results of this study prove that GCG through high institutional ownership can function as part of internal control and can supervise management in the implementation of income smoothing in improving earnings quality. The role of GCG$\mathrm{IO}$ is also able to force managers to carry out earnings management so that they do not violate the rules or are still in the normal/normal stage. This can be taking after Beidleman (1973) explanation which clarifies that salary smoothing is characterized as 'efforts on the portion of company administration to decrease irregular varieties in profit to the degree allowed by great bookkeeping and administration standards. GCGIO as the largest owner is also able to carry out supervision of managers to disclose more comprehensive information per the concept of GCG transparency. The results of this study are following the research of Murwaningsari (2014) which explains that the higher the institutional ownership, the higher the supervision of the institutional owner to disclose more comprehensive information. Through the role of GCG as a strong internal control, it can monitor the implementation of earnings management properly, so that any income smoothing efforts that are carried out increase the quality of earnings that are informed in transparency, accountability, and accountability. This is by the opinion of Sulistyanto (2008) that GCG is an internal and external process and controller. The result of this study are in line with Shubita (2015) who found the effect of income smoothing on earnings quality.

Based on Table 4 also shows that good corporate governance does not moderate the effect of earnings persistence on earnings quality. Therefore, hypothesis $4 \mathrm{~b}$ is rejected. Through the role of governance, which is owned by a larger institution within the company, the company is not able to provide supervision to management to maintain earnings persistence following the standards by taking advantage of existing regulatory loopholes. This can happen if the objectives of the stakeholders who make the policy have the same view that the implementation of GCG can become an obstacle to its goals in the company. The use of earnings persistence mechanisms by management has also forced management to take actions that are not following the concept of GCG transparency, accountability, and responsibility. The presence of institutional ownership as the majority, on the contrary, can be used to not implement GCG properly, so that the use of earnings persistence is not able to inform the market of good earnings quality. The results of this study are also input for policymakers so that the implementation of GCG-IO through its roles and functions becomes mandatory for every corporate entity in providing quality information transparency. This consider isn't in line with Hardiningsih, Hadi, and Ariani (2018) which found that there's an viable part of corporate administration in lessening forceful administration activities so that the quality of profit will be reacted to emphatically by speculators.

Based on Table 4, it also shows that good corporate governance weakens the effect of the book-tax difference on earnings quality. Therefore, hypothesis $4 \mathrm{c}$ is rejected. The results of this study show that the presence of GCG-IO reduces the quality of earnings itself, this is the possibility of the failure of the role of GCG-IO according to the regulations implemented. Even the presence of GCG-IO as the majority owner of the most powerful in making decisions is used to do tax evasion incorrectly, so this directly affects the quality of earnings. For example, by accruing costs/adding costs to reduce tax profits, then by adding costs that are not in the main cost component, indirectly the quality of earnings displayed in the financial statements becomes less transparent and profits do not reflect what they are. This can be done by the company's management if the GCG-IO's power is used to seek personal/group gain and try to avoid paying taxes that they should. The results of this study are input for policymakers both accounting standards and tax regulations to further develop rules for the majority institutional owners who are more assertive in disclosure or transparency reporting and make this BTD reported in more detail as in the disclosure of negative and positive corrections in tax regulations. The results of this study are not in line with the research of Huang and Wang (2013) which did not find a significant relationship between permanent BTD and earnings quality.

\section{Conclusion}

\subsection{Conclusion and Implication}

This study find that earnings persistence reduces the value of earnings quality, and the book-tax difference increases the value of earnings quality, while income smoothing has no impact on earnings quality. Institutional ownership was found to strengthen the effect of income smoothing on earnings quality and weaken the effect of book-tax differences on earnings quality, while no moderating effect was found on earnings persistence and earnings quality. The results of this study can be used by investors in analysing the company's financial statements to assess the level of earnings quality so that the available information can assist investors in predicting future earnings to the desired return on investment.

The implications of the research for management, practitioners, and policymakers where the results of this study can provide another view on the quality of earnings in manufacturing companies, especially regarding how the distribution of profits is carried out by considering good governance. 


\subsection{Limitation and Recommendation}

The limitations of this study are included in the research methodology, especially in measuring the difference in book taxes, which only uses tax burden data based on annual corporate income taxes, besides the limitations of researchers both in terms of funds, time and knowledge are still limited.

In addition, the results of this study can provide input to policymakers regarding book-tax differences so that disclosures in financial statements can be further developed according to tax regulations, not just revealing time differences and temporary differences in terms of accounting standards. As for academics, this research can develop literature on earnings persistence that is easier to understand in the application of improving earnings quality. The development of the Book tax differences measurement by expanding the meaning of the tax burden does not only use Corporate Income Tax data. In addition, measuring GCG involves more technical aspects of the scope of tax disclosure that companies can combine in carrying out good governance. Finally, this research is expected to be used as an additional reference for further research in the field of financial accounting and taxation.

\section{References}

Alhadi, S. A., Senik, R., \& Johari, A. J. (2018). Institutional ownership and earnings quality pre- and post-IFRS. International Journal of Economics and Management, $12(\mathrm{~S} 2), 747-757$.

Ames, D. S., Hines, C., \& Sankara, J. (2014). Are earnings quality attributes reflected in financial strength ratings? American Journal of Business, 29(3/4), 293-311. Available at: https://doi.org/10.1 108/AJB-12-2013-0073.

Aryati, T., \& Walansendouw, Y. C. (2013). Analysis of the effect of company diversification on earnings management. Journal Of Accounting And Auditing, 9(2), 244-260. Available at: https://doi.org/10.14710/jaa.9.2.244-260.

Asma, T. N. (2013). Effect of cash flow and differences between accounting profit and fiscal profit on earnings persistence. Accounting Journal, 1(1), 1-18.

Barnhat, S. W., \& Rosenstein, S. (1998). Board composion, managerial ownership, and firm performance: An empirical analisys. Financial Review, 33(4), 1-16. Available at: https://doi.org/10.1111/j.1540-6288.1998.tbo1393.x.

Beidleman, C. R. (1973). Income smoothing: The role of management. The Accounting Review, 48(4), 653-667.

Blaylock, B., Shevlin, T., \& Wilson, R. J. (2012). Tax avoidance, large positive temporary book-tax differences, and earnings persistence. The Accounting Review, 87(1), 91-120. Available at: https://doi.org/10.2308/accr-10158.

Demski, J. (1998). Performance measure manipulation. Contemporary Accounting Research, 15(3), 261-285. Available at: https://doi.org/10.1111/j.1911-3846.1998.tbo0560.x.

Djamaludin, S., Wijayanti, H. T., \& Rahmawati, R. (2008). Analysis of the effect of differences between accounting profits and fiscal profits on the persistence of earnings, accruals, and cash flows in banking companies listed on the Jakarta stock exchange. Indonesian Journal of Accounting Research, 11(1), 1-11.

Dridi, W., \& Adel, B. (2016). Book-tax differences and the persistence of earnings and accruals: Tunisian evidence. Asian Social Science, 12(6), 193-202.

Eckel, N. (1981). The income smoothing hypothesis revisited. Abacus, 17(1), 28-40. Available at: https://doi.org/10.1111/j.1467-6281.1981.tbo0099.x.

Ezat, A. M., Mohamed, A. M., Abulaila, M., Jaradat, S. A. N., Amin, A. Z., \& Abdelmajeed, S. H. (2019). Measuring earning quality in Saudi Arabia insurance companies. International Journal of Applied Engineering Research, 14(23), 42944309.

Fontanella, A., \& Martani, D. (2014). Effect of company characteristics on book tax differences (BTD) on listed companies in Indonesia. Paper presented at the National Accounting Symposium, XVII, Paper No. 97.

Gultom, R. R., \& Ahmar, N. (2016). Stubben earnings management, governance, and corporate values in the basic and chemical industry In Indonesia. Paper presented at the Proceedings of the INDOCOMPAC National Seminar.

Guthrie, J., \& Petty, R. (2000). Intellectual capital: Australian annual reporting practices. Journal of Intellectual Capital, 1(3), 241-251. Available at: https://doi.org/10.1108/14691930010350800.

Hanlon, M. (2005). The Persistence and pricing of earnings, accruals and cash flow when firms have large book tax differences. The Accounting Review, 8O(1), 137 - 166. Available at: https://doi.org/10.2308/accr.2005.80.1.137.

Hardiningsih, P., Hadi, T. P., \& Ariani, N. (2018). Determinant earnings persistence with corporate governance as moderating factors. Paper presented at the Proceeding of the International Conference on Banking, Accounting, Management, and Economics (ICOBAME 2018).

Harry. (2015). Management performance analysis. Jakarta: Gramedia Compass. PT.

Hery. (2010). Portrait of the internal audit profession. Bandung: Alfabeta.

Himmah, E. F. (2018). An Analysis of the effect of earnigns persistence, good corporate governance, and accrual component to earnings quality on banking in Indonesia in 2011-2015. Airlangga Accounting and Business Research Journal, 3(1).

Huang, D. F., \& Wang, C. L. (2013). Book-tax differences and earnings quality for the banking industry: Evidence from Taiwan. Pacific Accounting Revier, 25(2), 145-164.

Hunt, A., Moyer, S. E., \& Shevlin, T. (2000). Earnings volatility, earnings management, and equity value. Retrieved from: https://citeseerx.ist.psu.edu/viewdoc/download?doi=10.1.1.129.8282\&rep=rep 1\&type=pdf.

Irawati, D. E. (2012). The effect of capital structure, profit growth, firm size and liquidity on earnings quality. Accounting Analysis Journal, 1(2), 1-6.

Jensen, M. C., \& Meckling, W. (1976). Theory of the firm: Managerial behavior, agency cost and ownership structure. Journal of Finance Economic, 3(4), 305- 360. Available at: https://doi.org/10.1016/0304-405X(76)90026-X.

Kangarlouei, S. J., Motavassel, M., \& Rezvani, A. (2012). The Investigation of the effect of income smoothing on the reported earnings quality of active collapsed companies in Tehran Stock Exchange (TSE). Global Business and Management Research, 4(2), 220-232. 
Kartikahadi, H., Sinaga, R. U., Syamsul, M., Siregar, S. V., \& Wahyuni, E. T. (2016). IFRS-based financial accounting (2nd ed.). Jakarta: Indonesian Institute of Accountants.

Kevin, W. (2011). Changes in the predictive ability of earnings around earnings restatements. Review of Accounting and Finance, $1 O(2), 155-175$. Available at: https://doi.org/10.1108/14757701111129625.

Kirschenheiter, M., \& Melumad, N. (2002). Earnings' quality and smoothing. Retrieved from: https://citeseerx.ist.psu.edu/viewdoc/download?doi=10.1.1.203.4114\&rep=rep1\&type=pdf. $\quad$ Accessed June 2021].

Lev, B., \& Nissim, D. (2004). Taxable income, future earnings, and equity value. The Accounting Review, 79(4), 1039-1074.

Mehrani, S., Moradi, M., \& Eskandar, H. (2017). Institutional ownership type and earnings quality: Evidence from Iran. Emerging Markets Finance and Trade, 53(1), 54-73.

Murwaningsari, E. (2014). Institutional ownership and audit quality on information disclosure and future earnings response coefficient. Journal of Finance and Banking, 18(2), 161-171.

Novianti, R. (2012). Study of earnings quality in manufacturing companies listed on the IDX. Accounting Analysis Journal, $1(2), 7-12$.

Pasaribu, M. Y., Topowijono, \& Sulasmiyati, S. (2016). The effect of capital structure, ownership structure and profitability on firm value in basic and chemical industrial sector companies listed on the Stock Exchange in 2011-2014. Journal of Business Administration, 35(1), 154-164.

Pratiwi, H., \& Handayani, B. D. (2014). The effect of profitability, managerial ownership and taxes on income smoothing practices. Accounting Analysis Journal, 3(2), 264-272.

Richardson, S. A., Sloan, R., Soliman, M. T., \& Tuna, A. I. (2001). Information in accruals about the quality of earnings. SSRN Electronic Journal. Available at: https://doi.org/10.2139/ssrn.278308.

Ronen, J., \& Sadan, S. (1981). Smoothing income numbers: Objectives, means and implication. Massachusetts: Addison-Wesley.

Ross, S. (1977). The determinant of financial structure: The incentive signaling approach. Bell Journal of Economics, 8(1), 23-40. Available at: https://doi.org/10.2307/3003485.

Rusydi, M. K., \& Martani, D. (2014). The effect of ownership structure on aggressive tax avoidance. Paper presented at the National Symposium on Accounting, XVII. Paper No. 101

Sankar, M. R., \& Subramanyam, K. R. (2001). Reporting discretion and private information communication through earnings. Journal of Accounting Research, 39(2), 365-386. Available at: https://doi.org/10.1111/1475-679X.00017.

Sari, D., \& Lyana, I. D. D. (2016). Book tax differences dan kualitas laba. Multiparadigm Accounting Journal, 6(3), 399-411.

Scott, W. R. (2009). Financial accounting theory (5th ed.). Canada: Prentice Hall.

Scott, W. R. (2012). Financial accounting theory (6th ed.). Canada: Prentice Hall.

Shubita, M. F. (2015). The impact of income smoothing on earnings quality in emerging markets: Evidence from GCC markets. Journal of Accounting in Emerging Economies, 5(3), 299-324. Available at: https://doi.org/10.1 108/JAEE04-2011-0011

Sismi, \& Martani. (2014). The effect of differences in accounting profits with tax profits and family ownership on earnings persistence. Paper presented at the National Accounting Symposium, XVII, Paper No. 102.

Stubben, S. R. (2010). Discretionary revenues as a measure of earnings management. The Accounting Revierw, 85(2), 695717. Available at: https://doi.org/10.2308/accr.2010.85.2.695

Sulistyanto, S. H. (2008). Earnings management, theories and empirical models. Jakarta PT: Gramedia Widiasrana Indonesia.

Sumbari, S., Murni, Y., \& Masri, I. (2017). Analysis of dependent tax expense and accruals in detecting earnings management. Paper presented at the IV Accounting Scientific Conference on 2-3 March 2017.

Tang, Y. H. (2006). The value relevance of book-tax differences - an empirical study in China's capital market. SSRN Electronic Journal. Available at: https://doi.org/10.2139/ssrn.897120.

Tang, Y. H. T., \& Firth, M. (2012). Earnings persistences and stock market reaction to the difference information in book tax differences: Evidence from China. The International Journal of Accounting, 47(3), 369-397. Available at: https://doi.org/10.1016/j.intacc.2012.07.004.

Tehranian, H., Cornett, M. M., Marcus, A. J., \& Saunders, A. (2006). Earnings management, corporate governance, and true financial performance. SSRN Electronic Journal, 30. Available at: http://dx.doi.org/10.2139/ssrn.886142.

Tucker, J. W., \& Zarowin, P. A. (2006). Does income smoothing improve earnings informativeness? The Accounting Review, 81(1), 251-270. Available at: https://doi.org/10.2308/accr.2006.81.1.251.

Tucker, J. W., \& Zarowin, P. A. (2016). Does income smoothing improve earnings informativeness? The Accounting Review, $81(1), 251-270$.

Yuniati, M., Raharjo, K., \& Oemar, A. (2016). The effect of dividend policy, debt policy, profitability and ownership structure on firm value in manufacturing companies listed on the Indonesia Stock Exchange 2009-20014. Journal of Accounting, 2(2), 1-15.

Zhong, L., Chourou, L., \& Ni, Y. (2017). On the association between strategic institutional ownership and earnings quality: Does investor protection strength matter? Journal of Accounting and Public Policy, 36(6), 429-450. 